\title{
The Urgency Of The Formation Of Village Regulations Concerning Customary Institutions In Creating Legal Protection For The Adat Community Of Ngadisari Village Sukapura Sub-District Probolinggo District
}

\author{
Indah Dwi Qurbani \\ indah.qurbani80@ub.ac.id \\ Faculty of Law, Universitas Brawijaya \\ Muhammad Lukman Hakim \\ em.lukman79@ub.ac.id \\ Faculty of Law, Universitas Brawijaya \\ Tunggul Anshari S.N \\ tunggul@ub.ac.id \\ Faculty of Law, Universitas Brawijaya
}

Submitted: Okt 9, 2020; Reviewed: Okt 23, 2020; Accepted: Dec 1, 2020

Article's Information

Abstract

Keywords: Formation of Village Traditional Institutions; Village Regulation.

DOI:

https://doi.org/10.25041/constitutionale.v1i2.2119

Abstract
The existence of customary
institutions in the village is important
because it has a duty to assist the
Village Government and as partners
in empowering, preserving and
developing customs. The Village
Customary Institution can occupy its
rank with official recognition from
the Government through a Village
Regulation. Ngadisari Village was
chosen as the object of this research
because it has its own uniqueness,
this village has indigenous people
who are still strong in maintaining the
traditions of their ancestors' heritage.
Meanwhile, Ngadisari village also
has a customary institution that
carries out customary functions and is

The existence of customary institutions in the village is important because it has a duty to assist the Village Government and as partners in empowering, preserving and developing customs. The Village Customary Institution can occupy its rank with official recognition from the Government through a Village Regulation. Ngadisari Village was chosen as the object of this research because it has its own uniqueness, this village has indigenous people who are still strong in maintaining the traditions of their ancestors' heritage. Meanwhile, Ngadisari village also has a customary institution that carries out customary functions and is 
part of the original village structure that grows and develops on the initiative of the village community. The research method used is a type of empirical research and using sociological approach. The order of village regulations regarding customary institutions in order to make Adat Institutions as an alternative to dispute resolution, maintain local culture and play a role in village development. In addition, this formalization effort is also needed to maintain the existence of customary villages, provide legal protection and help cooperation between traditional village institutions of Ngadisari and other village customary institutions. This is in accordance with the duties of the customary institutions in Permendagri Number 18 of 2018 concerning Village Community Institutions and Village Traditional Institutions.

\section{A. Introduction}

The formation of laws and regulations in a democratic constitutional state is no longer merely an area of domination by the executive (bureaucrats) and parliament, but has also become part of the people's responsibility to participate in it. As a subject who will receive the impact of the enactment of laws and regulations, the community will take part in determining the priority policy direction for the Formulation of Legislation. Without community involvement in its formation, it is impossible for a statutory regulation to be accepted and implemented properly. ${ }^{1}$

In addition, it is realized that one of the important prerequisites for producing responsive legal products is community participation. According to Nonet and Selznick, the importance of community participation in the formation of legal products must be seen in the participatory formation process by inviting as much participation as all elements of society, both from the perspective of individuals or community groups. Besides that, it must also be an aspiration which comes from the desire or will of the community. ${ }^{2}$

In relation to the formation of this participatory law, it contains two meanings, namely: process and substance. The process is a mechanism in the formation of legislation that must be carried out transparently, so that from the aspirations of the community it can participate in

\footnotetext{
${ }^{1}$ Yuliandri, Laporan Akhir Pengkajian Hukum Tentang Partisipasi Masyarakat Dalam Penentuan Arah Kebijakan Prioritas Penyusunan Peraturan Perundang-Undangan, Pusat Penelitian Dan Pengembangan Sistem Hukum Nasional Badan Pembinaan Hukum Nasional Kementerian Hukum Dan Hak Asasi Manusia Ri 2014, pg, 6.

${ }^{2}$ Nonet dan Selznick, Law and Society in Transition: Toward Rensponsive Law, dalam Yuliandri, Laporan Akhir Pengkajian Hukum Tentang Partisipasi Masyarakat Dalam Penentuan Arah Kebijakan Prioritas Penyusunan Peraturan PerundangUndangan, Pusat Penelitian Dan Pengembangan Sistem Hukum Nasional Badan Pembinaan Hukum Nasional Kementerian Hukum Dan Hak Asasi Manusia RI2014.
} 
providing input in regulating a problem. Substance is the material to be regulated and must be aimed at the interests of the wider community, resulting in a law that is democratic, inspirational, and participatory and has a responsive/populist character. Participation, transparency and democratization in the formation of laws and regulations constitute an integral and inseparable part of a democratic country. ${ }^{3}$

\section{Conception of Public Aspirations in the Formation of Legislation}

Community aspirations are a series of activities in the form of demands or "resistance" to a policy which is carried out systematically and in an organized manner. The aim is to influence the formation or change of policies as an effort to convey the interests of the community. To represent ideas, the people can still voice their aspirations through various media, including print media, electronic media, and other conventional media which are constitutionally guaranteed in the context of respecting human rights. By understanding the importance of community aspirations, the material content will be more pro-interests of the people. Any misappropriation of content aimed at the interests of the people means denying the essence of the existence of laws in the midst of society. The enactment of laws that are not in favor of the public interest will be dangerous for the survival of the life order of the wider community. ${ }^{4}$

The formation of a law is considered aspiration, if in the process it takes into account the aspirations of the community. According to Satjipto Raharjo (1986: 114), a law is said to be aspiration and participatory, if it can produce regulations that have the following characteristics:

1) General and comprehensive in nature, thus constituting special and limited goodness and characteristics;

2) It is universal, because laws are formed to deal with events in the future. Therefore, laws cannot only be formulated to deal with certain incidents; and

3) Has the power to correct and improve itself. It is customary for a regulation to include a clause that contains the possibility of a review.

If accommodated, the people's aspirations can increase legitimacy, transparency and responsiveness, and are expected to produce accommodative policies. ${ }^{5}$

\section{Community Participation in the Formation of Village Regulations}

Regulation on villages before the enactment of Law no. 6 of 2014 concerning Villages is regulated in Law no. 32 of 2004 concerning Regional Government. As it is known that the regulation regarding villages is regulated together with the provisions on Government in the regions in one Law. In Article 1 number 12. The Law on Regional Government provides a definition of a village, namely a legal community unit that has territorial boundaries that is authorized to regulate and manage the interests of the local community, based on local origins and customs which are recognized and respected in the State Government system of the Republic of Indonesia. ${ }^{6}$

On 18 December 2013 the Government passed Law no. 6 of 2014 concerning the Village. The new Village Law is an important milestone for village administration, because of the real willingness of the Central Government to empower villages. Some of the considerations for the passing of the Village Law are that villages have rights of origin and traditional rights in regulating and managing the interests of local communities and play a role in realizing the

\footnotetext{
3 Joko Riskiyono, Partisipasi Masyarakat Dalam Pembentukan Perundang-Undangan Untuk Mewujudkan Kesejahteraan, Aspirasi Vol. 6 No. 2, Desember 2015, pg, 160.

${ }^{4}$ Ibid,pg 161.

${ }^{5}$ Ibid,pg 161.

${ }^{6}$ Kadar Pamuji Dkk, Partisipasi Masyarakat Desa Dalam Penyusunan Peraturan Desa, Jurnal Idea Hukum, Vol 3 No 1 Tahun 2017, pg, 495-496.
} 
ideals of independence based on the 1945 Constitution of the Republic of Indonesia (UUD NRI 1945). In order to regulate and manage household affairs, one of the things the village can do is to formulate village regulations. To ensure that village regulations have benefits that can be felt by the community, village regulations must be formulated with community participation. $^{7}$

According to Tomy M Saragih, public participation in a democratic government order requires public involvement in the decision-making process. ${ }^{8}$

Society's participation in development is not only viewed as a part of a process but also a part of purpose, which participation is one of the indicators of achievement especially village development program. Therefore, participation has double functions which as a tool to organize development and as the purpose of the development itself. ${ }^{9}$

There are at least 4 (four) models of community participation in the formation of democratic Village Regulations: first, involving community members who are considered experts and independent in a team or working group in the formation of village regulations; second, conducting public hearings (public discussions) through seminars, workshops or inviting interested parties (stakeholders) to meetings for drafting village regulations; third, conduct validity tests on certain parties to obtain responses; fourth, holding deliberation activities on village regulations before being discussed by the competent institution; fifth, publish the draft village regulation in order to get community responses. ${ }^{10}$ These legal products of Village governments are: ${ }^{11}$

1. Village Regulations

2. Head Village Joint Regulation

3. Head Village Regulation.

The Village Regulation is stipulated by the Head Village after being discussed and agreed upon with the Village Consultative Body which is a legal and policy framework in the administration of Village Government and Village Development. The stipulation of Village Regulations is a description of the various powers that the village has with reference to the provisions of higher laws and regulations. As a legal product, the Village Regulation must not conflict with higher regulations and must not harm the public interest:

1) Disturbance to public harmony.

2) Disturbance to public service access.

3) Disturbance of public peace and safety.

4) Disturbance to economic activities to enhance villagers' prosperity.

5) Iscrimination towards ethnicity, religion, beliefs, race, groups, and gender.

As a political product, Village Regulations are processed in a democratic and participatory manner, that is, the drafting process includes participation of the Village community. The Village Community has the right to propose or provide input to the Village Head and Village Consultative Body in the process of drafting Village Regulations. ${ }^{12}$

\footnotetext{
${ }^{7}$ Ibid.

${ }^{8}$ Tomy M Saragih, Konsep Partisipasi Masyarakat Dalam Pembentukan Peraturan Daerah Rencana Detail Tata Ruang Dan Kawasan, Jurnal Sasi Vol. 17 No. 3 Bulan Juli-September 2011.

${ }^{9}$ Teraik Kogoya, dkk., Partisipasi Masyarakat Terhadap Pembangunan Infrastruktur Jalan Desa Di Kabupaten Lanny JayaPapua, Jurnal Berkala Ilmiah Efisiensi, Program Pascasarjana, Program Studi Perencanaam Pengembangan Wilayah Universitas Sam Ratulangi, Manado, Volume 15 no. 2 - Juni 2015, pg, 3.

${ }^{10}$ Muhammad Syaifudin dkk, Demokrasi Peraturan Desa, Jurnal Masalah-masalah Hukum, Fakultas Hukum Universitas Diponegoro, Jilid 39 No. 2, Juni Tahun 2010, pg. 106-118.

${ }^{11}$ Article 69 paragraph (1) Law Nomor 6 of 2014 on Village

${ }^{12}$ Description on Law Nomor 6 of 2014 on Village
} 
Village regulations that regulate village authority based on rights of origin. Village-scale authorities are supervised by the Village community and the Village Consultative Body. This is intended so that the implementation of Village Regulations can always be monitored continuously by the local Village community members considering that Village Regulations are established for the benefit of the village community. ${ }^{13}$

To assess a participatory village regulation formation, we need to determine the village as the object of study, therefore in this study the authors chose Ngadisari village, Probolinggo district to be the object of research. Ngadisari Village was chosen as the object of research because it has its own uniqueness, this village has indigenous people who are still strong in maintaining the traditions of their ancestors, meanwhile in Ngadisari village it also has traditional institutions that carry out traditional functions and become part of the original structure of the village that grows and develops on the initiative of the village community. ${ }^{14}$ The existence of customary institutions in the village is important because it has a duty to assist the Village Government and as partners in empowering, preserving and developing customs as a form of recognition of the customs of the village community. ${ }^{15}$

Seeing the importance of customary institution's functions in a village, it is necessary to have regulations that guarantee the existence of customary institutions in the village, so that their existence is recognized in the State of Indonesia. Besides that the institutionalization of village customary institutions and regulations is also important as legitimacy for customary leaders to collaborate with government agencies, NGOs, and other customary institutions. In order to realize regulations that can accommodate the needs of customary institutions in the Ngadisari village, community participation is needed to create a responsive legal product.

From the introduction above, the formulation of the problem that can be drawn is: What is the importance of establishing Village Regulations regarding customary institutions for the development of law in Indonesia, especially the Ngadisari Village Customary Institution? This research method uses empirical juridical research with a sociological approach. The procedure used to solve research problems by examining secondary data first then interview by conducting research on primary data in the field. It takes the ability to identify legal problems, make legal considerations, analyze problems, and provide solutions to these problems. ${ }^{16}$ This research was conducted in Ngadisari Village, Sukapura District, Probolinggo Regency, where there is one indigenous community unit there, namely Tengger. The legal materials used in this research are the Minister of Home Affairs Regulation Number 18 of 2018 concerning Village Community Institutions and Village Traditional Institutions, and regional regulations. This legal material research technique uses observational data obtained from interviews with informants who are directly involved in this case the Ngadisari Village Head, the Head of Community and Village Empowerment Service or Dewan Pemberdayaan Masyarakat dan Dewan (DPMD) Probolinggo Regency, and the Head of the Probolinggo Regency Law Section. Then the secondary material is all related legal publications. Furthermore, the literature study is carried out by taking an inventory of regulations and grouping them according to the regulatory hierarchy.

\footnotetext{
${ }^{13} \mathrm{Ibid}$.

${ }^{14}$ Article 1 Paragraph (1) Ministry Regulation Nomor 18 Tahun 2018 on Village Customary Institution.

${ }^{15} \mathrm{Ibid}$, Article 10 Paragraph (1).

${ }^{16}$ Peter Mahmud Marzuki, Penelitian Hukum, Edisi Revisi, Prenada Media Group, Jakarta, 2016.
} 


\section{B. Discussion}

\section{The Urgency of Customary Institution Recognition in Indonesia's Governmental System}

a. Customary Institution as an Alternative Dispute Settlement

In line with the strengthening of the regional autonomy system, there has also been an awareness of the importance of local wisdom and dispute resolution systems based on customary law. Therefore, the government, both through laws or and ministerial regulations, is pushing to revive customary institutions, one of whose duties and functions is to resolve disputes between citizens or members of their groups. The development of customary institutions still raises problems, among others, that customary institutions derive from customary law. The weakness of regulation at the statutory level can be found in two laws that recognize the existence of customary institutions as a dispute resolution mechanism. ${ }^{17}$

One of the laws that explicitly state the role of customary institutions in dispute resolution is Law No.7 of 2012 concerning Social Conflict Handling. The law even clearly states that social conflict resolution prioritizes settlement through customary institutions. This means that resolving social conflicts in the regions must prioritize mechanisms through customary institutions. When the customary mechanism has been adopted, all parties including the government must acknowledge the results of conflict resolution through this customary institutional mechanism. If it fails, through customary institutions, it will be taken through other mechanisms. However, this Law also recognizes the limitations of customary institutions, so that there is a formula that states the existing customary institutions and their existence is recognized. This formula emerged because it was realized that not all regions still maintain and develop customary institutions. Thus, the recognition of the existence of customary institutions in Law no. 7 of 2012 is not optimal, because this Law does not encourage the strengthening of customary institutions, but only acknowledges if it still exists, because this Law does not obviate any efforts to revive or develop local wisdoms for solving social conflicts. Law No. 6 of 2014 concerning Villages contains a few provisions to strengthen customary institutions to carry out the functions of customary institutions, including the function of dispute resolution. The vague arrangements at the statutory level then provide space for each region to strengthen customary institutions. ${ }^{18}$

b. Maintaining Local Culture

Customary villages are of particular concern to the government as a means of growing and preserving local wisdom, customs and cultural values of the Indonesian people. According to Santoso, currently the existence of local wisdom is felt to be fading away in various groups of society. The waning existence of local wisdom cannot be separated from the reality of modernization and globalization. As stated by Ife and Tesoriero that in order to face cultural globalization, it is very difficult for people to preserve their own local culture which is the uniqueness of their region, whereas according to Piotr Sztompka in his book, Sociology of Social Change, it deals with modernization views and the desire to catch up with society. At the most advanced, there is a readiness to embrace the Western pattern as a means or condition for the emancipation of society or at least as a symbol of the progress of civilization. ${ }^{19}$

Globalization has opened wide the fabric of interactions and transactions between individuals, groups and between countries which have political, economic, social and cultural implications as well as science and technology at different levels and intensities. Indonesia

\footnotetext{
${ }^{17}$ Inosentius Samsul,Penguatan Lembaga Adat Sebagai Lembaga Alternatif Penyelesaian Sengketa, Jurnal Negara Hukum: Vol. 5, No. 2, November 2014, pg, 128.

${ }^{18}$ Ibid, 128-129.

${ }^{19}$ Muhammad A. Rauf, Politik Hukum Pembentukan Desa Adat Dalam Sistem Pemerintahan Di Indonesia, Jurnal De Lega Lata, Volume I, Nomor 2, Juli - Desember 2016, pg, 419.
} 
clearly cannot be separated from the massive influence of globalization, seen from the tendency of people to prefer to use foreign products and cultures. Norms in the legal context emphasize that globalization has a big influence, where the development of the Indonesian legal system tends to prefer civil law and common law systems and Indonesian legal politics which leads to the codification and unification of law. This situation has practically caused the waning of the role of customary law institutions in Indonesia. Even though we realize it or not, customary law is a legal institution that is able to counteract the effects of globalization that are contrary to the noble values and positive laws that exist in Indonesia

Globalization, which is largely the result of Western thinking, cannot be fully adapted by Eastern nations (including Indonesia), which also have culture and norms that morally become something that must be carried out by the people. Until now, customary law pluralism in Indonesia has grown dynamically following the development of its society while still relying on the characteristics of indigenous peoples and the coschmish participatory mindset. The mindset that puts forward this balance is believed to be still relevant to be applied in current developments, because in fact this mindset is very much in line with the spirit of sustainable development or sustainable development. In addition, providing space for customary law to survive and develop means providing justice for the customary law community, because in this way, it can ensure that the rights of the customary law community as mandated by the constitution are maintained, so that they are no longer marginalized. Apart from providing protection, it is also necessary to have room for customary law to act as a filter against the effects of globalization that are incompatible with the traditions and culture of the East. One proof that the role of the community is in this case is how traditional villages in Bali continue to grow and consistently carry out traditional activities, amid the rapid development of global class tourist objects throughout the island of Bali. ${ }^{20}$

c. The Role of Ngadisari Customary Institution in Village Development

Role is everything that is done by a person or group based on their position and function normatively in society. ${ }^{21}$ In economic development and development in general, the regulation of economic life in developing countries often uses economic dualism, on the one hand maintaining an economic system that has been regulated for generations and traditionally while also using a modern economic system influenced by developed countries. Reviving indigenous peoples and their customary institutions today is a universal trend. The protection of indigenous indigenous peoples in UNDRIP emphasizes that indigenous peoples have special autonomy which cannot automatically comply with national law. There is a need for wisdom in observing and further regulating indigenous peoples into the national legal system. Regulations regarding customary villages and villages are important things to be researched and used for deeper discussion. ${ }^{22}$

Village and village arrangements are subject to reform and development as regulated in Article 3 of Law No. 6 of 2014 concerning Villages and Government Regulation No.43 of 2014: Village Arrangements are based on: a. recognition; b. subsidiarity; c. diversity; d togetherness; e. mutual cooperation; f. kinship; g. discussion; h. democracy; i. independence; j. participation; k. equality; 1. empowerment; and m. continuity. Types of villages in Article 6 of Law No. 6 of 2014: village consists of villages and traditional village. The mention of Village or Traditional Village as referred to in paragraph (1) shall be adjusted to the designation that applies in the local area. Development is a social change or modernization of the community, in this case the village community and customary village. Regulations

\footnotetext{
${ }^{20}$ Ibid, pg420-421.

${ }^{21}$ Wedy Nasrul, Peran Kelembagaan Lokal Adat Dalam Pembangunan Desa, Jurnal Ekonomi Pembangunan Volume 14, Nomor 1, Juni 2013.

${ }^{22}$ Agus Pribadiono, Lembaga Desa Adat Dalam Pembangunan Desa Menurut UUNo. 6 Tahun 2014: Antara Kemandirian Dan Subordinasi Pengaturan, Lex Jurnalica Volume13 Nomor 1, April 2016, pg, 18.
} 
enhances on the importance of development values on human resources in village communities and customary villages. Increased understanding of the development of human resources and technology appropriately set forth in village laws. ${ }^{23}$

Article 80 (1) The Village Development Planning as referred to in Article 79 shall be carried out by involving the Village community. In further regulation regarding village development Law Number 6 of 2014 concerning Villages does not specifically regulate customary villages. Traditional villages are defined as Indigenous people where the level of authority cannot be subordinated by the local government system. Customary village development has its own specifications and the autonomous government above must respect these indigenous peoples. ${ }^{24}$

d. Tengger Ethniticy existence

The Tengger tribe originated from the Majapahit kingdom when it experienced a decline. After the death of Maha Patih Gajah Mada in 1364, Majapahit remained victorious under Hayam Wuruk's reign and managed to maintain its glory until he died in 1389. Majapahit's power was then ruled by Wikramawardana, Hayam Wuruk's son-in-law. ${ }^{25}$ The Tengger tribe strongly believes in and respects the dukun in their area because the dukun is very influential in the life of the Tengger people. The Tengger community upholds the values of equality, democracy and community life, the figure of a shaman is more respected than an administrative leader. The perch community has its own laws outside the formal laws that apply in the country. With this law they are able to regulate and control various problems in the life of their community. ${ }^{26}$

A customary head has a spiritual and social function. The spiritual function of the traditional shaman is to lead traditional ceremonies. Meanwhile, its social function is to act as a mediator between society and affairs related to government. In addition, traditional healers also have certain powers in making decisions, rules, sanctions, or social fines for violators of customary laws and regulations. ${ }^{27}$

In legal matters, the Society Tengger still adhere to the customary laws of their ancestors and traditions or customs that are still traditional in settling cases that occur based on customary law. Before colonialism entered Indonesia and introduced legal products and their solutions, the Indonesian people already had customary law and customary settlement or in other words before the colonial period Indonesia already had legal products and their solutions which were commonly called customary courts. Customary courts have been around for a long time before the community recognized how to resolve disputes through litigation in court. Before getting to know written procedural law, the community had practiced judicial procedures to resolve disputes (both civil and criminal disputes) through the customary court system which was based on unwritten legal regulations that were born from collective agreement. $^{28}$

In civil matters, for example, inheritance, the Tenggerese use customary law. We recommend that before we discuss the issue of inheritance in the Tengger community, we must first understand the terms that are closely related to inheritance issues, some of these terms include:

The definition of inheritance in general is all property left by someone who dies (heir), whether the property has been divided or not divided or not divided. So when talking about

\footnotetext{
${ }^{23}$ Ibid,pg, 19.

${ }^{24}$ Ibid, pg, 21.

25 M. Junaedi Al Anshori. 2007. Sejarah Nasional: Masa Pra Sejarah Sampai Masa Proklamasi Kemerdekaan Jakarta:PT.Mitra Aksara Panaitan,pg, 34.

${ }^{26}$ Fatmawati, Peran Pemangku Adat Suku Tengger Dalam Menjalankan Sistem Hukum Adat, Jurnal Universiatas Jember, Vol 5 No 1 (2016), pg, 81.

${ }^{27} \mathrm{Ibid}$, Pg 82.

${ }^{28}$ Ibid, pg 84 .
} 
the law of inheritance, especially talking about inheritance, it means we are questioning the wealth of a person (heir) because he has died, and whether that person's property will (can) be divided, or cannot be divided or cannot be divided. Actually, the inheritance property is shared by the owner to the residents (heirs), but in terms of the distribution of the inheritance according to customary law it is influenced by the characteristics of harmony and togetherness, it is also still influenced by a sense of family unity and a sense of brotherhood integrity. ${ }^{29}$

The form and system of inheritance law are closely related to the form of society and kinship. While the kinship system in Indonesian society is based on the system of drawing lineages, as is known in Indonesia in general, at least three kinds of descent systems are known: ${ }^{30}$

1. The Patrilineal System / Fatherhood; This system is in principle a system that draws the lineage or lineage of its male ancestors. This system is widely found in communities in the areas of Tanah Gayo, Alas, Batak, Ambon, Irian Jaya, Timor and Bali.

2. The Matrilineal System / Mother Nature; a system that draws the mother's lineage and so on upwards takes the lineage of the female ancestor. This system exists in the Minangkabau community.

3. Bilateral or Parental System / motherhood; is a system that draws lineages both through the father's and maternal lines, so that in this kind of kinship there is virtually no difference between the mother and the father, this system in Indonesia is found in the people of Java, Madura, East Sumatra, Riau, Aceh, Sumatra South, All Kalimantan, Sulawesi, Ternate and Lombok.

The Tengger society, which are people who live on the island of Java, like other Javanese, the Tengger people draw a lineage based on bilateral principles, namely the lineage of the father and mother. The smallest kinship group is the nuclear family consisting of a husband, wife and children.

In connection with the problem of land in the Tengger society which has its own uniqueness, the lands in the Tengger area must be inherited from generation to generation and they will not sell their land other than to the Tengger community itself and that too must be limited to their relatives or the original inhabitants of Tengger. This is because there are regulations that prohibit selling land or renting land to immigrants or people outside the Tengger community. The people of Tengger strongly adhere to these rules, because the lands in the Tengger area are inherited from their ancestors which will later be passed down from generation to generation to the next (future) generation or the native Tenggerese. The Tenggerese do not want their land to be owned and controlled by the immigrant community. Inheritance to offspring is determined by the willingness of the parents, not on the basis of strict standardized rules. ${ }^{31}$

In principle, the Tenggerese are classified as a bilateral or parental kinship system, in which the system basically does not differentiate between the sexes of men and women. The position of sons and daughters in terms of dividing inheritance is equal. However, according to Sri Hajati and Abd. Shomal, the distribution of inheritance which is divided equally

\footnotetext{
${ }^{29}$ Noor M. Aziz, Laporan Akhir Tim Pemantauan Dan Inventarisasi Perkembangan Hukum Adat Badan Pembinaan Hukum NasionaL, Kementerian Hukum Dan Hak Asasi Manusia RI Badan Pembinaan Hukum Nasional Jakarta 2011, pg 46-47.

${ }^{30}$ M. Idris Ramulyo, Suatu Perbandingan antara Ajaran Syafi'i dan Wasiat Wajib di Mesir, tentang Pembagian Harta Warisan untuk Cucu Menurut Islam, Majalah Hukum dan Pembangunan No. 2 Th.XII Maret 1982, Jakarta: FH UI, 1982, pg. 155 .

${ }^{31}$ Op.cit,pg 49.
} 
(balance) actually sometimes will harm one party, if the other party is too passive in the activity of collecting assets. ${ }^{32}$

Unfortunately, so far the existence of customary institutions has not been formalized, based on the results of our interview with the village head Ngadisari on July 13, 2020. There are some information that we get, including:

1. So far, customary institutions have only been recognized by the customary community, but they have not been formalized in the form of village regulations. In terms of the formalization process of this customary institution, it is important because later they will have a permanent secretariat and a permanent management, ${ }^{33}$ this will facilitate the process of solving cases, inventorying cases, taking inventory of the local culture that still exists. Not only that, this formalization process will also recognize customary institutions not only in the village but also in other areas, because their existence is legally and formally valid. ${ }^{34}$

2. Ngadisari Village is very supportive of the existence of customary institutions, according to the narrative of the village head Ngadisari, the village government has made many policies through perdes to preserve customs in the village of Ngadisari, but unfortunately until now there are no village regulations on customary institutions.

3. The village community is very supportive of formalizing the traditional village institution of Ngadisari, this will have an impact on the existence of their customary village. It's just that they don't know the procedure for establishing customary institutions through this village regulation.

Therefore, we try to provide assistance for the process of forming the traditional institution of the Ngadisari village, this is one form of acceptance that we do to maintain the culture.

\section{Conclusion}

The existence of a traditional village cannot be separated from the participation of the management of traditional institutions, to maintain the existence of traditional villages, it is necessary to recognize their customary institutions, because this institution is responsible for preserving and introducing the culture of Ngadisari Village. Not only that this customary institution is also tasked with resolving conflicts using its customary law, therefore the existence of village customary institutions must be a serious concern by the village government, one way to maintain the existence of customary institutions is to carry out the formalization process through village regulations. which guarantees the existence of customary institutions in the village, so that their existence is recognized in the Indonesian State, besides that the institutionalization of village customary institutions through village regulations is also important as legitimacy for customary leaders to collaborate with government agencies, NGOs and other customary institutions. In order to realize regulations that can accommodate the needs of customary institutions in the Ngadisari village, community participation is needed to create a responsive legal product.

\footnotetext{
${ }^{32}$ Ibid, pg 50.

${ }^{33}$ Syarat Pendirian Lembaga Adat Desa, Lihat Permendagri Nomor 18 tahun 2018 tentang Lembaga Kemasyarakatan Desa dan Lembaga Adat Desa.

${ }^{34}$ Salah satu tugas Lembaga adat desa ialah mengembangkan kerja sama dengan LAD lainnya hal ini tercantum dalam Permendagri Nomor 18 tahun 2018 tentang Lembaga Kemasyarakatan Desa dan Lembaga Adat Desa.
} 


\section{Bibliography}

A. Book

Al Anshori, M. Junaedi. 2007. Sejarah Nasional: Masa Pra Sejarah Sampai Masa Proklamasi Kemerdekaan.Jakarta:PT.Mitra Aksara Panaitan.

Aziz,Noor M. Laporan Akhir Tim Pemantauan Dan Inventarisasi Perkembangan Hukum Adat Badan Pembinaan Hukum Nasional, Kementerian Hukum Dan Hak Asasi Manusia Ri Badan Pembinaan Hukum Nasional Jakarta 2011.

Marzuki,Peter Mahmud. Penelitian Hukum, Edisi Revisi, Prenada Media Group, Jakarta, 2016.

Nonet dan Selznick, Law and Society in Transition: Toward Rensponsive Law, dalam Yuliandri, Laporan Akhir Pengkajian Hukum Tentang Partisipasi Masyarakat Dalam Penentuan Arah Kebijakan Prioritas Penyusunan Peraturan Perundang-Undangan, Pusat Penelitian Dan Pengembangan Sistem Hukum Nasional Badan Pembinaan Hukum Nasional Kementerian Hukum Dan Hak Asasi Manusia RI 2014.

Ramulyo, M. Idris. Suatu Perbandingan antara Ajaran Syafi'I dan Wasiat Wajib di Mesir, tentang Pembagian Harta Warisan untuk Cucu Menurut Islam, Majalah Hukum dan Pembangunan No. 2 Th.XII Maret 1982, Jakarta: FH UI, 1982.

Yuliandri, Laporan Akhir Pengkajian Hukum Tentang Partisipasi Masyarakat Dalam Penentuan Arah Kebijakan Prioritas Penyusunan Peraturan Perundang-Undangan, Pusat Penelitian Dan Pengembangan Sistem Hukum Nasional Badan Pembinaan Hukum Nasional Kementerian Hukum Dan Hak Asasi Manusia RI 2014.

B. Journal

A. Rauf, Muhammad. Politik Hukum Pembentukan Desa Adat Dalam Sistem Pemerintahan Di Indonesia, Jurnal De Lega Lata, Volume I, Nomor 2, Juli - Desember 2016.

Fatmawati. Peran Pemangku Adat Suku Tengger Dalam Menjalankan Sistem Hukum Adat, Jurnal Universiatas Jember, Vol 5 No 1 (2016).

Kogoya,Teraik dkk. Partisipasi Masyarakat Terhadap Pembangunan Infrastruktur Jalan Desa Di Kabupaten Lanny Jaya-Papua, Jurnal Berkala Ilmiah Efisiensi, Program Pascasarjana, Program Studi Perencanaam Pengembangan Wilayah Universitas Sam Ratulangi, Manado, Volume 15 no. 2 - Juni 2015.

Nasrul, Wedy. Peran Kelembagaan Lokal Adat Dalam Pembangunan Desa, Jurnal Ekonomi Pembangunan Volume 14, Nomor 1, Juni 2013.

Pamuji, Kadar Dkk. Partisipasi Masyarakat Desa Dalam Penyusunan Peraturan Desa, Jurnal Idea Hukum, Vol 3 No 1 Tahun 2017.

Pribadiono, Agus. Lembaga Desa Adat Dalam Pembangunan Desa Menurut UU No. 6 Tahun 2014: Antara Kemandirian Dan Subordinasi Pengaturan, Lex Jurnalica Volume13 Nomor 1, April 2016.

Riskiyono, Joko. Partisipasi Masyarakat Dalam Pembentukan Perundang-Undangan Untuk Mewujudkan Kesejahteraan, Aspirasi Vol. 6 No. 2, Desember 2015.

Samsul,Inosentius. Penguatan Lembaga Adat Sebagai Lembaga Alternatif Penyelesaian Sengketa, Jurnal Negara Hukum: Vol. 5, No. 2, November 2014.

Syaifudin, Muhammad dkk. Demokrasi Peraturan Desa, Jurnal Masalah-masalah Hukum, Fakultas Hukum Universitas Diponegoro, Jilid 39 No. 2, Juni Tahun 2010. 
C. Regulations

Peraturan Menteri Dalam Negeri Republik Indonesia Nomor 18 Tahun 2018 Tentang Lembaga Kemasyarakatan Desa Dan Lembaga Adat Desa.

Undang-undang Nomor 6 Tahun 2014 Tentang Desa. 